\title{
18. MUD VOLCANISM ON THE MEDITERRANEAN RIDGE ${ }^{1}$
}

\author{
A.H.F. Robertson ${ }^{2}$ and Shipboard Scientific Party ${ }^{3}$
}

\begin{abstract}
Two different mud-dome structures (the Milano and Napoli Domes) on the northern margin of the Mediterranean Ridge accretionary complex were drilled during Ocean Drilling Program Leg 160 and were found to be active, or recently active, mud volcanoes. A transect of holes was drilled from adjacent hemipelagic deep-sea sediments, across the flanks, to the crestal areas of these structures. The dominant sediment types recovered are variably clast-rich matrix-supported muds ("mud breccias") that are interbedded and interfinger with deep-sea hemipelagic sediments. Lower in the sequence, intervals of inclined clastsupported gravel and sand, composed mainly of clay in both mud volcanoes, are overlain by matrix-supported clast-rich muds that are interpreted as multiple debris flows. Variably silty and sandy sediments characterize the crestal areas. Pore fluids at Napoli Dome, and to a lesser extent at Milano Dome, indicate the presence of halite of presumed Messinian age. Hydrocarbon gas was found to be actively venting from the crest of the Napoli mud volcano. Gas was also detected by drilling on the crest of the Milano mud volcano. In addition, methane hydrates (clathrates) were discovered for the first time in the Mediterranean, a few tens of meters beneath the crest of the Milano mud volcano. The Milano mud volcano is at least $1.5 \mathrm{~m} . \mathrm{y}$. old and is apparently now dormant, whereas the Napoli mud volcano was initiated during the interval from, or prior to, 1.5-1.2 m.y. and is currently active.
\end{abstract}

\section{INTRODUCTION}

Ocean Drilling Program (ODP) Leg 160 (March-April 1995) investigated the nature and origin of unusual mud domes, which were previously considered to represent the surface expression of mud diapirs or mud volcanoes, located on the northern part of the Mediterranean Ridge about $150 \mathrm{~km}$ south of Crete in the Eastern Mediterranean Sea (Fig. 1). We report preliminary findings that provide important insights into the anatomy, age, and origin of these structures. Their origin is also important to aid understanding of the tectonic processes related to the initial stages of continental collision in the Eastern Mediterranean. Two transects of holes were drilled from the flanks to the crestal areas of the Milano and Napoli structures.

\section{REGIONAL SETTING}

The mud volcanoes occur in several zones of the Mediterranean Ridge, of which the largest is the Olimpi Field, which is elongated subparallel to the east-northeast-west-southwest tectonic grain of the Mediterranean Ridge accretionary complex (Camerlenghi et al., 1992, 1995). The mud volcanoes form part of the "cobblestone topography" that is characteristic of the Mediterranean Ridge (Kastens et al., 1992). They were discovered and initially documented by Italian expeditions (Cita et al., 1981, 1989; Camerlenghi et al., 1992; Staffini et al., 1993). More recently, active fluid vents that are surrounded by bacteria and other chemosynthetic organisms were discovered (Limonov et al., 1994; Cita et al., 1995, in press; Corselli and Bossi, in press).

Two alternate hypotheses were tested by drilling during Leg 160 . First, the mud domes could be considered as intrusions of massive material that protruded above the level of the seafloor. Second, the

'Emeis, K.-C., Robertson, A.H.F., Richter, C., et al., 1996. Proc. ODP, Init. Repts., 160: College Station, TX (Ocean Drilling Program).

${ }^{2}$ Grant Institute of Geology, University of Edinburgh, West Mains Road, Edinburgh EH9 3JW, United Kingdom. a.robertson@ed.ac.uk

${ }^{3}$ Shipboard Scientific Party is given in the list preceding the Table of Contents. mud mounds could be true mud volcanoes that consist of mud debris flows extruded from a central vent (Brown and Westbrook, 1988). Previous workers recognized sedimentary facies that they believed to be both intrusive and extrusive, based on limited recovery in piston cores (Camerlenghi et al., 1992; Staffini et al., 1993). Drilling to 200 $\mathrm{m}$ and downhole geophysical logging offered an excellent opportunity to differentiate between intrusive and extrusive processes.

Geophysical site surveys confirm that both the Milano and Napoli mud volcanoes are distinctly asymmetric structures (Fig. 2). The Napoli structure is flat-topped and the flanks are surrounded by a shallow moatlike feature. The flanks of both volcanoes are underlain by inward-dipping reflectors, which imply that subsidence of the flanks has taken place over the lifetime of the volcano.

\section{MILANO MUD VOLCANO}

At the outermost hole (Hole 970B, Fig. 2A), the sediments comprise interbedded nannofossil oozes, nannofossil clays, and sapropels typical of the hemipelagic deposits in the region. These sediments are interbedded with poorly consolidated, thin- to medium-bedded sands and silts. Some intervals are tilted, and small normal and reverse faults are present. The hemipelagic sediments are dated as early to late Pleistocene, based on calcareous nannofossils and foraminifers. The outer flank area (Hole 970A) comprises alternations of mud debris flows and normal hemipelagic sediment. The section begins with a thin $(<1 \mathrm{~m})$ uppermost pelagic interval that is dated as younger than $0.26 \mathrm{~m} . \mathrm{y}$. This interval is underlain by thick (approximately $120 \mathrm{~m}$ ) clast-rich mud-supported sediments, followed by a thin interval of pelagic sediment that extends over the interval from about 0.99 Ma to about 1.5 Ma. The sequence continues downward with layered coarse-grained turbidites (Fig. 2A) with mud clasts at the base, together with minor graded sands and silts. This is then underlain by another interval, of normal pelagic sediments dated at $1.75 \mathrm{Ma}$.

Downhole geophysical logs, notably from the Formation MicroScanner (FMS), clearly image a pebbly fabric and define the main lithologic units, showing that the mud debris flows include numerous clasts of different lithologies that are mainly less than $5 \mathrm{~cm}$ in diameter (but locally up to $0.5 \mathrm{~m}$ in diameter). The FMS signatures also indicate that some coarse sediment is present beneath the lowest 


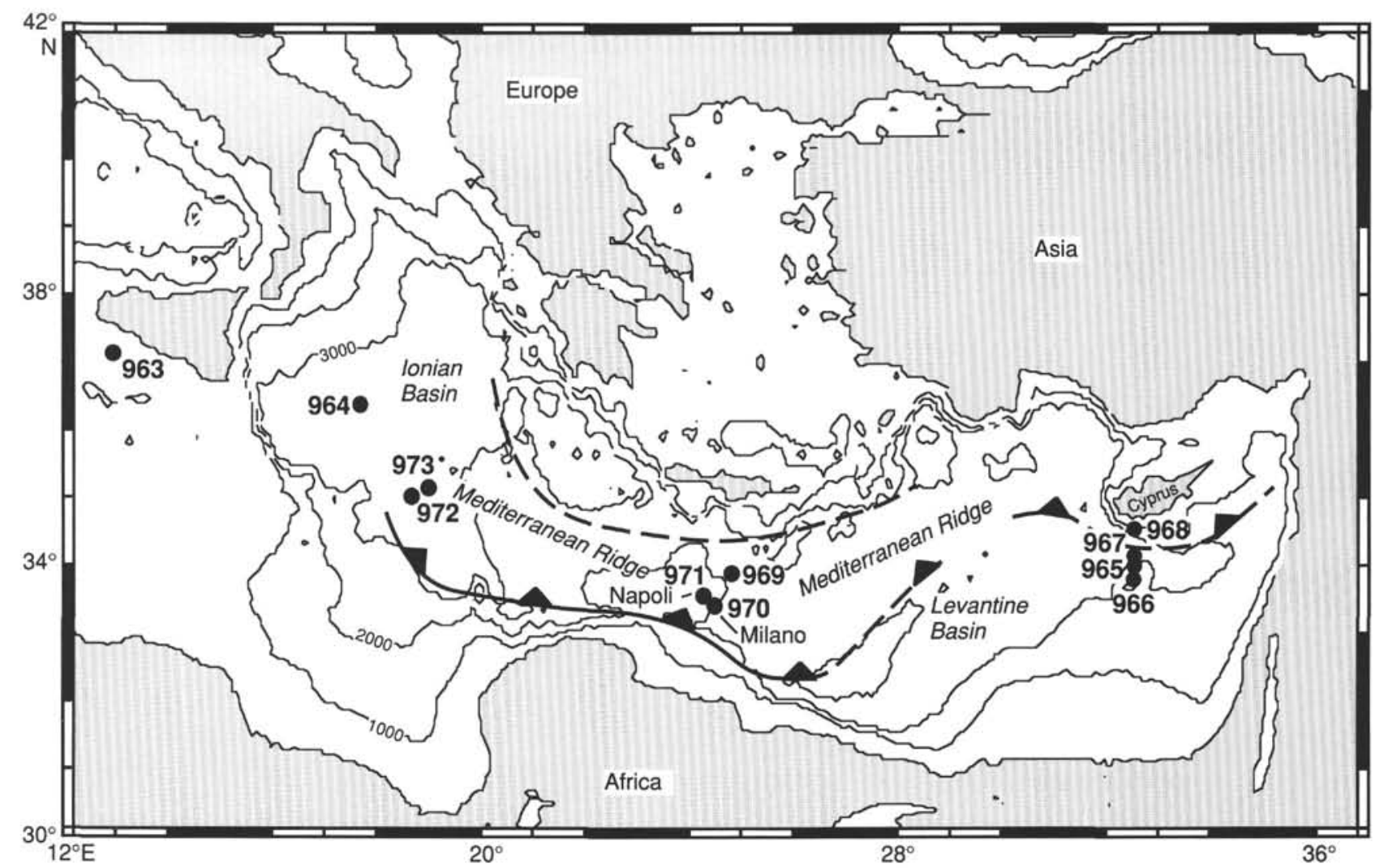

Figure 1. Outline map of the eastern Mediterranean region showing the location of the Milano (Site 970) and Napoli (Site 971) mud volcanoes drilled during Leg 160.

cored interval of pelagic sediment. Finally, "mousselike" (i.e., gaseous) muddy and silty sediments, with evidence for the presence of gas hydrates (see below), were recovered from the inner flank and crestal sites (Hole 970C and the top of Hole 970D).

\section{NAPOLI MUD VOLCANO}

The 200-m-deep Hole 971A, drilled on the flank of the Napoli Dome, cored interbedded nannofossil ooze, nannofossil clays, and turbidites, in which nannofossil and planktonic foraminifer ages range from the middle-late Pleistocene to the middle Pliocene (Fig. 2B). This sediment is underlain by clast-rich matrix-supported mud debris flows. The clasts $(15-25 \mathrm{vol} \%)$ are mainly calcareous and range from several millimeters to a few centimeters in size. Limited FMS and other log data indicate that the matrix-supported sediments contain numerous small clasts $(<5 \mathrm{~cm})$. The matrix is of similar composition in both the Milano and Napoli mud volcanoes. It consists of dominantly middle Miocene nannofossils and planktonic foraminifer assemblages, together with mixed Eocene, Oligocene, and middle Miocene forms. In addition, Pleistocene microfossils were found in the Napoli mud volcano.

The pelagic sediments above the matrix-supported debris flows are dated at slightly younger than $1.5 \mathrm{~m} . \mathrm{y}$. In addition, the lower part of this unit is within the large Gephyrocapsa Zone, which spans the interval from 1.25 to $1.5 \mathrm{Ma}$ in age. The lowermost part of the sequence also ends with an interval of hemipelagic sediment. Within the moat (Hole 971B), an upper unit, $20 \mathrm{~m}$ thick, of hemipelagic sediments (including sapropels) is underlain by mud debris flows that are dated between 0.26 and $0.46 \mathrm{Ma}$. Debris flows with scattered clasts alternate with more homogeneous silty clay. Downhole logs (especially the natural gamma-ray and resistivity) indicate the pres- ence of a number of thin layers that correspond to relatively sandy intervals. The logs also distinguish clast-rich and clast-poor intervals. Hole 971C was drilled at the same location as Hole 971B and an expanded sequence was recovered, possibly resulting from the redeposition of sediment from the crestal area of the mud dome into the moatlike depression. Hole 971D, also drilled on the crest of the mud dome, recovered mousselike (i.e., gaseous) silty clay, with scattered small $(<5 \mathrm{~cm})$ clasts of mudstone and siltstone. In addition, angular subrounded clasts of coarsely crystalline halite (up to $3 \mathrm{~cm}$ in size) were found in the thin, more silty layers, together with a small number of subrounded halite-cemented mudstone clasts $(<5 \mathrm{~cm}$ in size). These clasts could have been smoothed either during transport or as a result of partial dissolution. The matrix is essentially identical to that described above for the Milano mud volcano. Finally, Hole 971E comprises mousselike silty and sandy clays (Fig. 2B) with a few small $(<3 \mathrm{~cm})$ clasts of mudstone and fine-grained carbonate. Rare nannofossils of Pleistocene age are present in the upper part of the section, but are absent beneath this, whereas reworked Miocene nannofossils dominate the sequence.

\section{MUD VOLCANIC FACIES}

The predominant sediment type of the Napoli and Milano mud volcanoes is well-consolidated matrix-supported clast-rich material ("mud breccias"; Cita et al., 1989; Staffini et al., 1993), in which the matrix ranges from silty clay to rare sandy silt, together with nannofossils, foraminifers, clay, quartz, and rock fragments. During Leg 160 these sediments were termed "breccia/conglomerate." The clasts vary in shape from mainly subangular to subrounded and are less commonly angular or rounded. The clast lithologies include poorly consolidated sandstone and siltstone and weakly to well-consolidated 

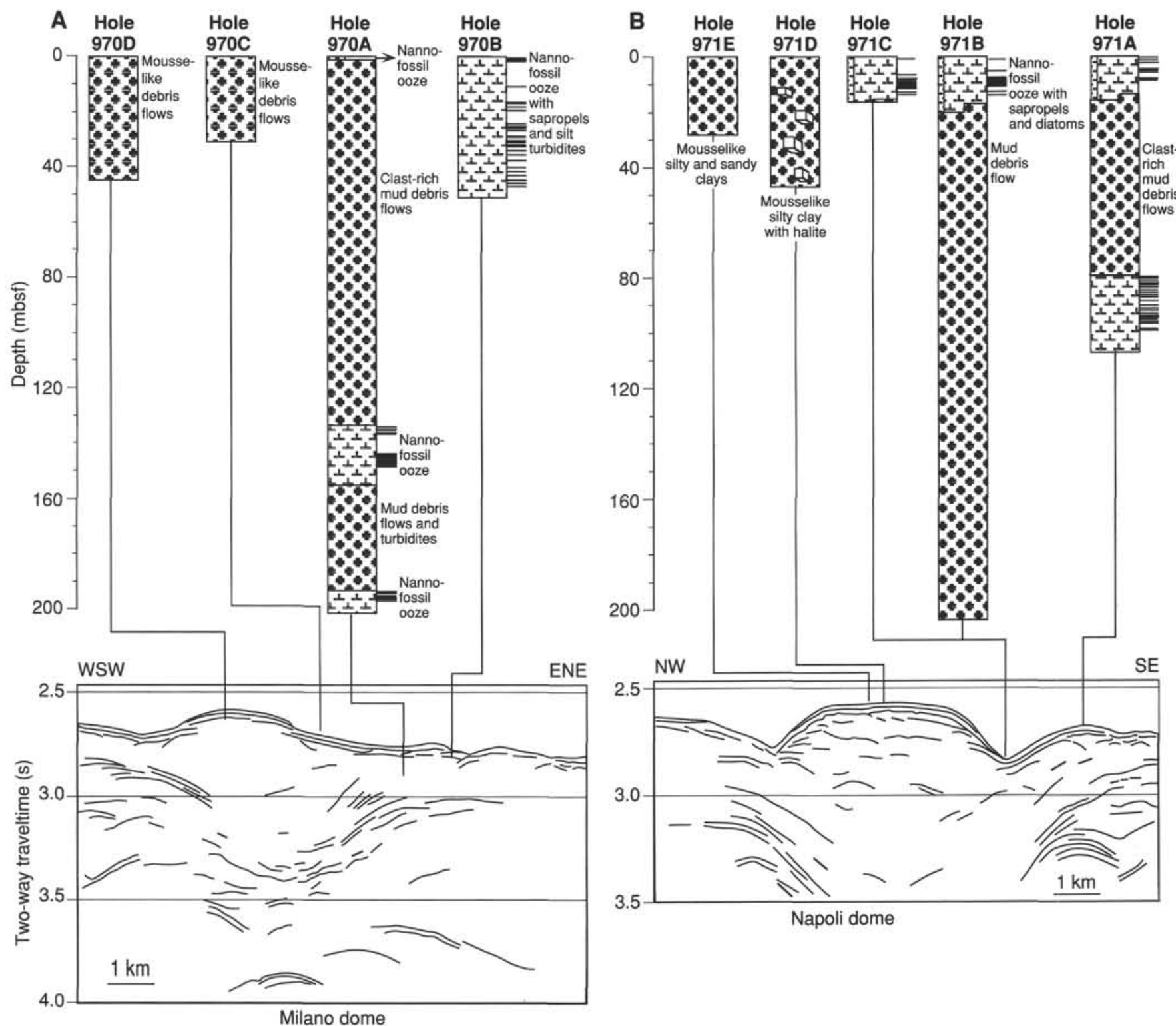

Napoli dome

Figure 2. Summary of the lithostratigraphy of the (A) Milano and (B) Napoli mud volcanoes drilled during Leg 160. The seismic reflectors visible within the two mud volcanoes are shown below. Note the presence of inward-dipping reflectors beneath both flanks of the Napoli and Milano structures (see text for description).

calcareous claystone and mudstone, together with calcite- or (locally) quartz-cemented sandstone and siltstone. These sediments are present in the flank sites of both mud volcanoes (Holes 970A, 971 A. and 971B). The matrix-supported sediments beneath the well-developed moat at Hole 971B are mainly layered muddy debris flows. On the flanks of the Milano mud volcano, where no moat is present, similar relatively clast-rich mud debris flows interfinger with hemipelagic sediment. Silty sediments, usually with mousselike textures, are present in the crestal sites of both mud volcanoes.

The sandstone clasts are mostly litharenites, derived from plutonic igneous and metamorphic source terrains, as well as from shallowwater carbonate rocks (e.g., calcareous algae and polyzoans and pelagic carbonates). The clasts in both the Milano and Napoli volcanoes contain (1) nannofossils and planktonic foraminifers of BurdigalianLanghian age; (2) mixed nannofossil and planktonic foraminifer assemblages of middle Miocene, Oligocene, and Eocene age, together with evidence of Cretaceous nannofossils; and (3) ostracodes of brackish-water affinities of late Messinian-early Pliocene age, known only from the Milano mud volcano.

The presence of clathrates (methane hydrates) was inferred in the crestal areas of the Milano mud volcano, based on the evidence that pore-water salinities decrease with depth in Holes 970C and 970D. This decrease is explicable by the decomposition of clathrates. Low sulfate levels in these holes may relate to intense bacterial sulfate reduction of the methane hydrate. Both volcanoes show evidence of the presence of hydrocarbon gas. In the crest of the Milano mud volcano (Hole 970D), pure methane is abundant in gas bubbles in the upper $30 \mathrm{~m}$, but methane concentrations drop sharply beneath this depth. High hydrocarbon levels increase downward with respect to methane, which is consistent with a relatively shallow origin for much of the methane.

The methane/ethane ratios in Holes 971B, 971D, and 971E vary from 10 to 40 overall, but at the Napoli mud volcano, values in individual holes remain constant with depth. In contrast to the Milano 
mud volcano, methane hydrates (clathrates) were not detected. The gas also contains several higher hydrocarbons up to hexane and a number of hydrocarbons that were not identified. Pore waters from the crestal holes are saturated with respect to halite in all cases. Brines in the lower part of Hole 971 A are unusually rich in potassium, suggesting that brine of more than one source may be present. High alkalinity throughout (approximately $80 \mathrm{mmol} / \mathrm{L}$ in Holes 971D and $971 \mathrm{E})$ probably resulted from microbial consumption of methane. Sulfate decreases sharply downward in Hole 971B. This probably indicates the existence of high rates of bacterial sulfate reduction and the existence of an organic-matter-rich substrate. A single temperature measurement of $16.1^{\circ} \mathrm{C}$ obtained in Hole 970D at $45 \mathrm{~m}$ below seafloor (mbsf) is $2^{\circ} \mathrm{C}$ above normal bottom-water levels. This may help to explain the absence of clathrates in the Napoli mud volcano, in contrast to the Milano mud volcano.

\section{DISCUSSION}

The sediments cored at the Napoli and Milano mud volcanoes show clear evidence of sedimentary layering, and an origin entirely by intrusion of viscous mud (including mud sills) can be excluded (Fig. 3). The main lines of evidence that favor extrusion rather than intrusion are (1) interbedding of undisturbed pelagic sediments on the flanks of the Milano volcano; (2) the absence of evidence of forceful injection (i.e., shearing or scaly clay development); (3) evidence of regular layering that is revealed by the FMS, with gradations between more clast-rich and clast-poor intervals; and (4) the overall age-stratigraphic relationships, especially in the Milano mud volcano, that are explicable by upward construction of a volcanic edifice through time.

The stratified debris flows and turbidites from the lower intervals of Hole $970 \mathrm{~A}$ record a relatively early phase of deposition of mainly clast-supported sediments (Fig. 3A). These sediments were possibly forcefully ejected to form an unstable volcaniclastic cone, subject to slumping and the generation of high-density turbidity currents. An intense seismic reflector is located no more than $50 \mathrm{~m}$ beneath the lowest clastic sediments recovered. A similar strong reflector of inferred Messinian age is located just beneath the interval drilled at Site 969. It is probable that the prominent seismic reflector subjacent to the Napoli and Milano mud volcanoes is also of Messinian age. If correct, little additional mud volcanogenic sediment is likely to be present beneath the 200-m-thick section recovered at Hole $970 \mathrm{~A}$ and, thus, the lower clast-supported sediments at both Napoli and Milano would record an early phase of mud volcanism.

Clastic deposition was followed by the ejection of matrix-supported, clast-rich muds, which are interpreted as subaqueous debris flows (Fig. 3B). These form the bulk of the flank sediments of both mud volcanoes. The inward-dipping seismic reflectors beneath the flanks of the mud volcanoes appear to dip increasingly steeply downward. This can be explained by subsidence throughout the period of activity, which produced a moat that is bathymetrically visible in the case of the Napoli Dome. The moat, in turn, was repeatedly inundated by mud debris flows. In the case of Milano, no moat is presently visible, but the existence of inward-dipping reflectors beneath the dome may indicate the former existence of a moat, similar to that of the Napoli dome. The presence, or absence, of a moat may reflect a balance between subsidence and debris-flow extrusion.

The crestal sediments at both volcanoes are silty and lack debris flows with large clasts ( $>1 \mathrm{~cm}$ in diameter). By comparison to igneous volcanoes, it is possible that the dense clast-rich mud flows were erupted from the volcano flanks, whereas finer material was erupted on the crestal sites. Solid halite in the crestal holes (e.g., Hole 971D) was introduced both as crystalline and halite-cemented clasts from the sequence beneath.

Hydrocarbon gas appears to flow continuously to the surface in the Napoli mud volcano and evidence of gas was also noted at Milano, but only at the crestal site. The presence of methane hydrates in the Milano crest, but not at Napoli, is perhaps explicable by the existence of higher pore-fluid temperatures and salinities of up to $300 \mathrm{~g} / \mathrm{kg}$, which acted to suppress clathrate formation at Napoli.

Areas of active mud diapirism and mud volcanism occur in a number of settings, of which the most important are (1) those associated with subduction and ejection of material through accretionary prisms (e.g., in Barbados, Java-Sumatra, Timor, the Makran; Brown and Westbrook, 1988) and (2) those within thick sedimentary basins that are subject to tectonic instability and/or sediment loading (e.g., Gulf of Mexico, Black Sea; Limonov et al., 1994). The two mud volcanoes drilled during Leg 160 form part of the Olimpi mud dome field. Deep-tow side-scan data suggest that the individual mud volcanoes vary greatly in scale and size in this area (Limonov et al., 1994). Well-defined mud volcanoes with central vents include the Toronto and Prometheus II structures. There are also large areas of "mud breccias," notably the Gelendzhik structure, that possibly formed by extrusion from a number of related vents. In addition, other structures are now mainly buried beneath pelagic sediments and are clearly inactive.

Camerlenghi et al. (1995) proposed a model in which gas-rich mud first erupts to the surface and spreads laterally into a circular depression (i.e., as a mud lake) caused by degassing and collapse of the host sediments. This phase is followed by periodic liquid mud extrusion, which results in interfingering with surrounding pelagic sediments (e.g., the Napoli structure). During the final stages, viscous

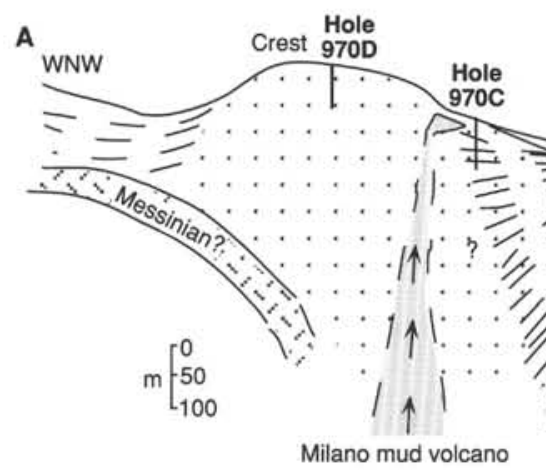

Milano mud volcano

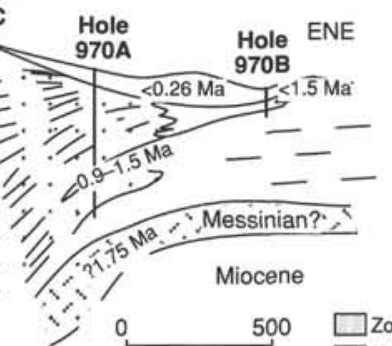

[. $" M^{n}$ r reflector, late Miocene

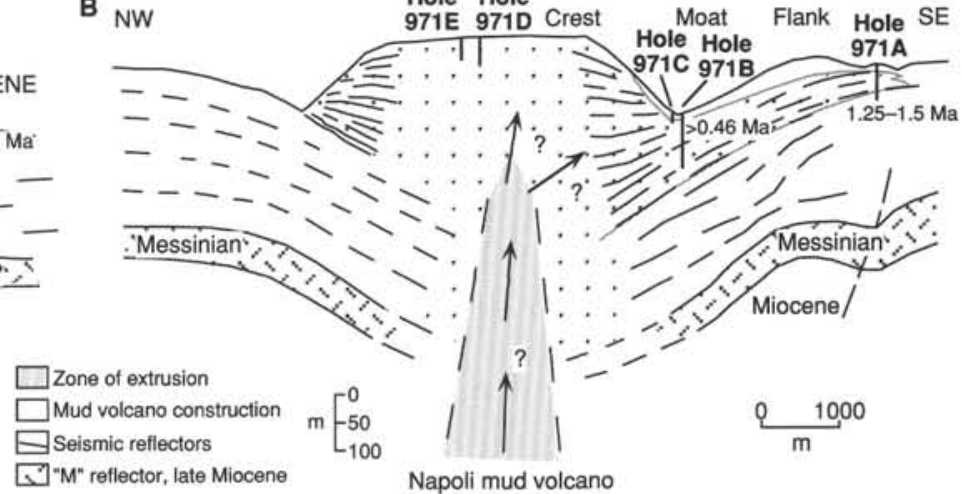

B $\mathrm{NW}$

Figure 3. Interpretation of the anatomy of the (A) Milano mud volcano and (B) Napoli mud volcano. Mud debris flows were extruded from the crestal area and accumulated mainly in a subsiding moat. 
mud is intruded, causing uplift to form a cone-shaped mud dome. A number of provisional points can be made from the data collected during Leg 160: (1) early eruption probably formed a clastic cone; (2) the overlying clast-rich sediments are interpreted as mainly relatively plastic debris flows, rather than very fluid mud flows; (3) extrusion of the debris flows occurred over an extended time interval, during which progressive subsidence of the flanks took place; and (4) the crestal area of the late-stage? Milano structure consists of silty debris flows rather than viscous mud intrusives.

One possibility is that siliciclastic and carbonate sediments within the clasts in the debris flows were eroded from the African continental margin that is being subducted beneath the Ionian Abyssal Plain, followed by ejection through the accretionary wedge to form mud volcanoes (Camerlenghi et al., 1995). Assuming a dip of $22^{\circ}$ for the subducting plate, the material was derived from $5.3-7-\mathrm{km}$ depths (Camerlenghi et al., 1995). The isotopic carbon signature of methane and the presence of appreciable quantities of $\mathrm{C}_{2+}$ hydrocarbon gases indicate a deep source of gas. However, the diagenesis of the clasts studied from Sites 970 and 971 and the composition of the clays do not indicate deep-burial diagenesis (e.g., no evidence of stylolites or low-grade metamorphism). It is therefore probable that much of the material was derived from a Miocene sequence located at relatively shallow depths (i.e., several kilometers at most). This can easily be envisaged if the dip of the subduction zone were much less than $22^{\circ}$.

Clasts of Late Cretaceous, Eocene, and Oligocene age, in addition to middle Miocene age, are also reported from other mud volcanoes, as in the Napoli and Milano mud volcanoes (Staffini et al., 1993; Premoli Silva et al., in press). The pre-Miocene microfossils within clasts at Milano and Napoli are entirely reworked within sediment of middle Miocene age, in agreement with Staffini et al. (1993). The siliciclastic sediment was derived mainly from plutonic and metamorphic source rocks, together with shallow-water carbonates and pelagic carbonate of early Tertiary and late Mesozoic age: similar lithologies exposed today on Crete (e.g., Hall et al., 1984) constitute a likely source area. If so, it is likely that the sedimentary clasts in the Milano and Napoli mud volcanoes originate from sediments that were deposited in a forearc basin, rather than in a subduction-trench setting.

The driving force of Mediterranean Ridge mud volcanism is most likely related to regional tectonic shortening, resulting from collision of the African and Eurasian plates (Camerlenghi et al., 1995; Fig. 4). The mud volcanoes appear to be located in an area of backthrusting against a backstop of continental crust or the Aegean forearc to the north (Truffert et al., 1993; de Voogd et al., 1992). Mud volcanism may have been initiated when fluid pressures increased within the Mediterranean Ridge at depth, related to crustal convergence of the African and Eurasian plates. This would have allowed clast-rich mud flows to rise episodically and to be extruded onto the seafloor as multiple debris flows. The water involved in mud volcanism is possibly pore fluid that was expelled in response to regional tectonic shortening. The matrix may have formed at least partly from clays interbedded with more lithified Miocene sandstones and limestones, although derivation from some deeper and older stratigraphic levels cannot be excluded.

\section{CONCLUSIONS}

The Milano and Napoli mud domes are interpreted as mud volcanoes. Early turbiditic deposition gave way to extrusion of multiple mud debris flows that interfinger with hemipelagic sediment. The distance of lateral transport of the debris flows is constrained to a maximum of $3 \mathrm{~km}$ (along the two transects studied). Finer grained, clast-poor, siltier and sandier sediments were erupted on the crestal areas of both sites. The presence of Messinian salt below the recovered intervals is indicated by the existence of salt-saturated pore-fluid

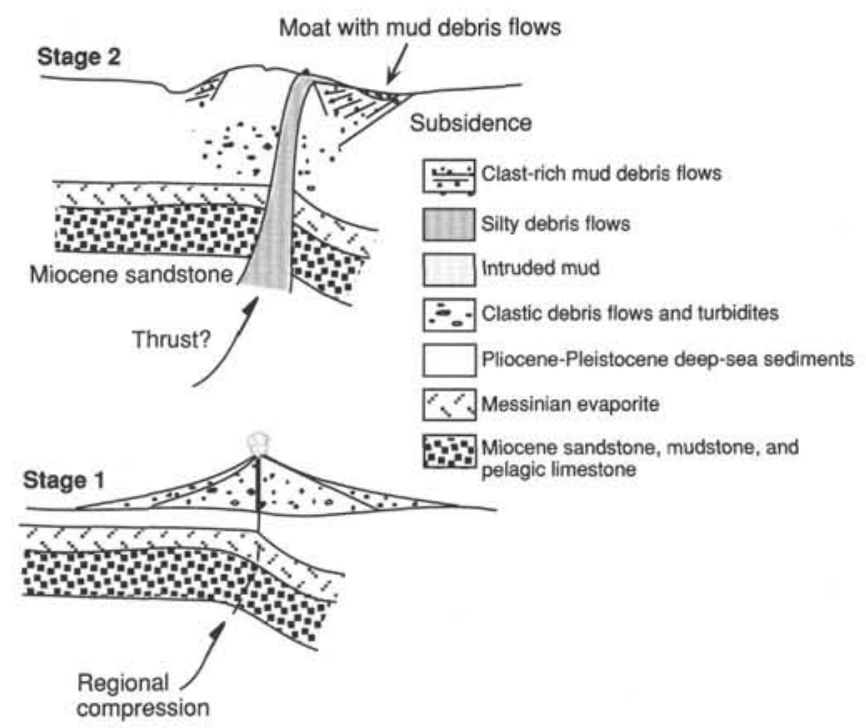

Figure 4. Stages of development of mud volcanism: (1) early explosive phase builds up a clastic cone and (2) collapse to form a moat that progressively fills with multiple debris flows.

compositions at all the Napoli dome sites and also at the crestal Milano sites. Evidence of active venting of hydrocarbon gas was observed at Napoli, together with minor gas at the Milano crestal sites. Methane hydrates are present at Milano, but not at Napoli. Activity at the Milano mud volcano began at, or before, approximately $1.75 \mathrm{Ma}$, and it is probably now dormant, whereas the Napoli mud volcano dates from 1 to 1.25 m.y. and is currently active.

\section{REFERENCES}

Brown, K., and Westbrook, G.K., 1988. Mud diapirism and subcretion in the Barbados Ridge accretionary complex: the role of fluids in accretionary processes. Tectonics, 7:613-640.

Camerlenghi, A., Cita, M.B., Della Vedova, B., Fusi, N., Mirabile, L., and Pellis, G., 1995. Geophysical evidence of mud diapirism on the Mediterranean Ridge accretionary complex. Mar. Geophys. Res., 17:115-141.

Camerlenghi, A., Cita, M.B., Hieke, W., and Ricchiuto, T.S., 1992. Geological evidence for mud diapirism on the Mediterranean Ridge accretionary complex. Earth Planet. Sci. Lett., 109:493-504.

Cita, M.B., Camerlenghi, A., Erba, E., McCoy, F.W., Castradori, D., Cazzani, A., Guasti, G., Giambastiani, M., Lucchi, R., Nolli, V., Pezzi, G., Redaelli, M., Rizzi, E., Torricelli, S., and Violanti, D., 1989. Discovery of mud diapirism in the Mediterranean Ridge: a preliminary report. Boll. Soc. Geol. Ital., 108:537-543.

Cita, M.B., Ryan, W.B.F., and Paggi, L., 1981. Prometheus mud-breccia: an example of shale diapirism in the Western Mediterranean Ridge. Ann. Geol. Pays Hellen., 30:543-570.

Cita, M.B., Woodside, J.M., Ivanov, M.K., Kidd, R.B., Limonov, A.F., and Scientific Staff of Cruise TTR3 Leg 2, 1994. Fluid venting, mud volcanoes and mud diapirs on the Mediterranean Ridge. Rend. Fis. Acc. Lin. Roma, 5:161-169.

, in press. Fluid venting from a mud volcano in the Mediterranean Ridge diapiric belt. Terra Nova.

Corselli, C., and Bossi, D., in press. First evidence of benthic communities based on chemosynthesis on the Napoli mud volcano (Eastern Mediterranean). Mar. Geol.

de Voogd, B., Truffert, C., Chamot-Rooke, N., Huchon, P., Lallemant, S., and Le Pichon, X., 1992. Two-ship deep seismic soundings in the basins of the eastern Mediterranean Sea (Pasiphae cruise). Geophys. J. Int., 109:536-552.

Hall, R., Audley-Charles, M.G., and Carter, D.J., 1984. The significance of Crete for the evolution of the Eastern Mediterranean. In Dixon, J.E., and Robertson, A.H.F. (Eds.), The Geological Evolution of the Eastern Mediterranean. Geol. Soc. Spec. Publ. London, 17:499-516. 
Kastens, K.A., Breen, N.A., and Cita, M.B., 1992. Progressive deformation on an evaporite-bearing accretionary complex: SeaMARC 1, SeaBeam, and piston-core observations from the Mediterranean Ridge. Mar. Geophys. Res., 14:249-298.

Limonov, A.F., Woodside, J.M., and Ivanov, M.K. (Eds.), 1994. Mud Volcanism in the Mediterranean and Black Seas and Shallow Structure of the Eratosthenes Seamount. UNESCO Rep. Mar. Sci., 64.

Premoli Silva, I., Erba, E., Spezzaferri, S., and Cita, M.B., in press. Variation in the age of the diapiric mud breccia along and across the axis of the Mediterranean Ridge accretionary complex. Mar, Geol.
Staffini, F., Spezzaferri, S., and Aghib, F., 1993. Mud diapirs of the Mediterranean Ridge: sedimentological and micropalaeontological study of the mud breccia. Riv. Ital. Paleontol. Stratigr., 99:225-254.

Truffert, C., Chamot-Rooke, N., Lallemant, S., de Voogd, B., Huchon, P., and Le Pichon, X., 1993. The crust of the Western Mediterranean Ridge from deep seismic data and gravity modelling. Geophys. J. Int., 114:360372

Ms 160IR-119 